\title{
CAPACITY BUILDING OF THE CAMAT IN DOING VILLAGE HEAD MANAGEMENT IN THE SUB-DISTRICT OF KERINCI KANAN, SIAK REGENCY
}

\author{
Tri Hariana \\ Program Studi Ilmu Pemerintahan, Universitas Islam Riau \\ Jl. Kaharuddin Nasution No.113 Perhentian Marpoyan, Pekanbaru, Indonesia \\ Moris Adidi Yogya \\ Program Studi Magister Ilmu Administrasi Publik, Universitas Islam Riau \\ Jl. Kaharuddin Nasution No.113 Perhentian Marpoyan, Pekanbaru, Indonesia \\ Corresponcensi Author: moris@soc.uir.ac.id
}

\begin{abstract}
The problem with this research is the lack of capacity building for the sub-district head in coaching village heads so that there are still some village heads who do not understand how to carry out their duties. The purpose of this study was to find out how the quality of the Camat's Capacity Building in Conducting Village Head Coaching in Kerinci Kanan District, Siak Regency. This study used qualitative research methods. The indicators in this study are human resources, organization and institutional reform. The use of this qualitative method aims to support the level of results so that they can be accounted for and easy to understand. This research data collection instrument prioritizes interviews as a means of obtaining the main raw materials to obtain appropriate results. The key informants of this research were the Kerinci Kanan Sub-district Head, Kerinci Kanan Village Head, Kerinci Kiri Village Head, Bukit Agung Village Head, and one of the people from each village. Based on the results of the discussion, it can be concluded that capacity building is not a process that starts from scratch but starts from building existing potential and then processed to further improve the quality of self, groups, organizations, and systems in order to survive in an environment that undergoes continuous change by utilizing cooperation between sub-district apparatus with village apparatus.
\end{abstract}

Keyword: Capacity Building, Development and District Government.

\section{INTRODUCTION}

In the context of overall development, capacity building efforts are an integral part. In other words, it is impossible for a development/development process to occur in any case without capacity building efforts for the actors as well as the system that regulates it.

The sub-district government is a tangible manifestation of a formal organization that functions to carry out government functions in general in serving the community. The sub-district government can be said to be the organizer of the government bureaucracy which is at a higher level than the Kelurahan/Village.

However, this task does not necessarily position the Camat as regional head as in the past. In terms of implementing the development and supervision of village government, the sub-district head has a very important role, because in the hierarchy of government the sub-district is one of the supra-village institutions, one of which is to carry out guidance and supervision of the village/kelurahan government in the context of orderly government administration. 
The most important thing from the Capacity Building function of a Camat in fostering is to be able to coordinate and collaborate with each government apparatus with the community, so that what is issued by the government can be carried out properly by the community. Thus, the creation of a civilized society, which supports every program and activity for the creation of a just and equitable development. It is hoped that the Village Head really must be active in adjusting the agendas set by the government.

Capacity Building carried out by the Camat in providing guidance to the Village Head is included in the concept of coaching, where the Camat is the highest leader in the sub-district in carrying out general government tasks and part of the autonomy affairs delegated by the Regent/Mayor to be carried out within the working area of the district. Efforts made by the Camat in order to facilitate the implementation of Village Head development in Kerinci Kanan District, namely increasing the Human Resources (HR) of the Village Head. In this case the implementation of technical guidance, the implementation of the specified training takes place at the Camat office. During the meeting the Village Heads were gathered and given training by the District Apparatus. It is hoped that this guidance carried out can reduce obstacles in the implementation of guidance to the Village Head, it will have a good impact on the smooth implementation of the Village government and services to the community.

Based on the description above, there are still many problems that the authors examine in Kerinci Kanan District, including the following: The Camat is only limited to conveying the procedures for the preparation of Perdas and Perkades in writing and at meetings of all Village Heads there is rarely any technical guidance. Here it can be seen that there are still village heads who make mistakes in carrying out their duties such as lack of understanding in each task because there is no direct practice and guidance regarding tasks, especially in the 3 (three) villages that the author studied.

The implementation of each village regarding participatory development planning has not been fully implemented. Where the village in the preparation of development planning only involves the LPM, the head of the RW, the head of the hamlet, and members of the BPD without fully involving the community, namely youth, youth organizations, religious leaders, education leaders.

Village administration facilities are one of the most important elements that must be fulfilled by every village in carrying out the village government. However, it can be seen that many villages in Kerinci Kanan District have not been able to fulfill village government administration, where the lack of clarity in village administration is found in the number of officers in the village, only 2-5 people, which results in the work of implementing village government being not optimal. Whereas several Village Heads in the Kerinci Kanan Sub-district, it is suspected that the Kerinci Kanan sub-district has not carried out their duties in accordance with Government Regulation Number 17 of 2018 article 10 in point (g) namely Fostering and supervising the administration of village governance in accordance with the provisions of the laws and regulations governing village, this can be seen from the 3 villages namely Kerinci Kanan Village, Kerinci Kiri Village and Bukit Agung Village in Kerinci Kanan Subdistrict that have not carried out government optimally.

There are still mistakes made by the village head in carrying out the duties of the village government in making village regulations and other supporting elements such as village infrastructure.

Based on the phenomena that have been described above, the writer is interested in conducting research entitled "Capacity Building for the Camat in Conducting Village Head Development in Kerinci Kanan District, Siak Regency".

Capacity building which states that human resource development is a series of systematic and planned activities designed by the organization to provide opportunities for its members to 
learn the skills needed to meet current and future job requirements. (Werner and De Simone, 2009:4 Daharti 2013:10).

UNDP Daharti (2013:11) further defines capacity building as a long-term process that continuously involves all stake holders, including government ministries, local governments, nongovernmental organizations, professionals, community members, academics, and further builds capacity using a country's human resources, scientific capabilities, technology, institutional organization and resources. The purpose of capacity building is to address issues related to development policies and methods, limiting the potential and needs of the people of the country concerned.

According to (Daniel Ricket in Hardjanto, 2006:67) states "the ultimate goal of capacity building is to enable the organization to grow stronger in achieving ats purpose and mission". It isfurther formulated that the objectives of capacity building are: 1. Accelerate the implementation of decentralization in accordance with applicable regulations. 2. Proportionate monitoring of tasks, functions, financial systems, mechanisms and responsibilities in the context of implementing regional capacity building. 3. Mobilize government, regional and other sources of funds; 4 . Use of funding sources effectively and efficiently.

Brown defines "capacity building is a process that increases the ability of persons, organizations or systems to meet its stated purposes and objectives". (Brown, Lisane et.al, 2001:25). Based on his opinion, capacity development is a process that can improve the ability of a person, organization or system to achieve the goals to be achieved.

Understanding the characteristics of capacity development according to (Milen, 2004; 16) that capacity development is certainly a continuous improvement process (continuous) from individuals, organizations or institutions, not only happening once. This is an internal process that can only be enabled and accelerated with outside assistance, for example donations (donors).

To be moreclear, Milen defines capacity as the ability of individuals, organizations or systems to define functions as they should effectively, efficiently, and continuously. Meanwhile, Morgan in Soeprapto formulates the notion of capacity as abilities, skills, understanding, attitudes, values, relationships, behaviors, motivations, resources, and conditions that enable each individual, organization, network/sector, and wider system. to carry out their functions and achieve the development goals that have been set from time to time. Furthermore, he sees capacity building as a special task, because the task is connected with factors in an organization or a certain system at a certain time. (Anni Milen, 2004:12).

This is in line with capacity development according to Merilee S. Grindle (1997:23) which states that capacity building is an effort that is reviewed for the development of a strategy to remind the efficiency, effectiveness, and responsiveness of government performance. Efficiency here in terms of the time and resources needed to achieve the outcome, efficiency in the form of appropriateness of effort made for the desired results and responsiveness of how to adjust between needs and abilities for that purpose.

Another definition of capacity building put forward by Marisson (2001:42) is to see capacity building as a process to carry out something, or a series of movements, multi-level change within individuals, groups, organizations and systems in order to strengthening the adaptability of individuals and organizations so that they can be responsive to changes in the existing environment. In fact, in some development literature, the concept of capacity building is still debating whether it is capacity building development or capacity strengthening, implying an initiative todevelop existing capacities. Meanwhile, other experts refer to coustructing capacity as a creative process to build capacities that do not yet exist.

However, Soeprapto does not lean on one side because according to him both have the same characteristics of the discussion, namely the analysis of the capacity of other initiatives to 
improve government performance (government performance). In this case, in line with Grindle's opinion, capacity building development is an effort intended to develop a strategic program to increase the efficiency, effectiveness, and responsiveness of government performance.

Grindle's explanation is clear enough that capacity building has dimensions, focus and types of activities. The dimensions of the focus and the type are: 1. Dimensions of HR development, with a focus on professional personnel and technicalcapabilities as well as types of activities such as training, hands-on practice, climatic conditions and recruitment. 2. Dimensions of organizational strengthening, with a focus on management governance to increase the success of roles and functions as well as activities such as incentive systems, personnel equipment, leadership, organizational culture, communication, managerial structure. 3. Institutional reform, with a focus on institutions and systems as well as macro structures, with types of activities, economic and political rules of the game, changes in policies and regulations and constitutional reform.

Based on the above theory regarding capacity building, the author uses the theory of Merilee S.Grindle (in Edralin, 1997:23) which states that capacity building has dimensions, focus and types of activities. The dimensions, focus and type of the author only focus on one point, namely the dimension of HR development, with a focus on professional personnel and technical capabilities as well as types of activities such as training, hands-on practice, climate conditions and recruitment. With output capacity building is an effort that is shown to develop a strategy to improve efficiency, effectiveness, responsiveness of government performance. Efficiency here is in the time and resources needed to achieve the outcome, efficiency in the form of the appropriateness of the effort carried out for the desired results and responsiveness in how to adjust the needs and abilities for that purpose.

\section{RESEARCH METHODS}

To obtain answers to the problems taken and in accordance with the objectives of this study, the type of research used in this research is descriptive research method through a qualitative research method approach. According to Isaac and Michael (Rachmat, 2005: 22) descriptive research method is a research method that aims to systematically describe the facts or characteristics of a particular population or a particular field in a factual and accurate manner. In addition, according to Burhan Bungin (Bungin, 2007: 68) descriptive research methods aim to describe, summarize various conditions, various situations, or various phenomena of social reality that exist in the community that are the object of research and seek to draw that reality to the surface as a feature, character, and trait. Models, signs or descriptions of certain conditions, situations or phenomena.

Based on the understanding of the descriptive research method from the experts, the research on Capacity Building of the Camat in Conducting Guidance in the Kerinci Kanan District, Siak Regency is appropriate to use descriptive research methods. In addition to using descriptive methods, this study also uses a qualitative research method approach. According to Bogdan and Taylor (Moleong, 2000: 3) qualitative research methods as research procedures that produce descriptive data in the form of written or spoken words from people and observable behavior. According to them, this approach is directed at the background and the individual holistically (whole). With the descriptive qualitative approach used in this study, the authors can obtain a complete picture of the problems formulated by focusing on the search process from any data in the field. With the hope that the information studied is more in-depth, natural and rational.

The author determines the research informants in this study amounted to 7 (seven) people, whichwere divided into 4 (four) people as formal informants and 3 (three) people as informal informants. Formal figures who become subjects or informants in this study are the Camat, Head of Kerinci Kanan Village, Head of Kerinci Kiri Village and Head of Bukit Agung Village. While the informal figures who became informants in this study were 3 (three) representatives from the village. 


\section{DISCUSSION}

After conducting research entitled Capacity Building for the Camat in Conducting Village Head Development in the Kerinci Kanan sub-district, Siak Regency. Then the respondent's data is in the form of data collection, namely interviews after conducting interviews and field observations to get research results with indicators that can be seen as follows:

\section{Human Resources}

Human resources (HR) is one of the most important factors that cannot even be separated from an organization, both institutional and company development. In essence, human resources are humans who are employed in an organization as movers, thinkers and planners to achieve organizational goals.

In this human resource indicator, it can be explained about the response of the Camat Capacity Building in Conducting Village Head Coaching in Kerinci Kanan District, Siak Regency. To see the results of the informants' answers to the Human Resources indicators as follows:

Based on the researcher's interview with the Kerinci Kanan Sub-district Head, Siak Regency, Mr. M. Hassanal Lutfi, S.STP when interviewed at the Kerinci Kanan Sub-district Office he said about what guidance activities were carried out for the village head. Following are the results of the interview:

For the activities carried out, we provide guidance to village heads and village officials regarding the implementation of village administration. The guidance that we carry out is to assist and provide direction regarding village administration and reports on the person in charge of village government administration, so that the village has no difficulty in completing village administration.

Based on the results of the interview above, the district government has carried out coaching activities to improve the human resources of village officials, namely providing guidance and training to village government officials.

The following is a follow-up interview with the Kerinci Kanan sub-district head regarding giving directions regarding the details of the tasks carried out by the sub-district head. The results of the interview are as follows:

As the sub-district government, we provide guidance such as informing the procedures for the preparation of village administration, financial management processes, and technical instructions for implementing village government activities, fostering village government administration, andfacilitating the preparation of village administration.

Based on the results of the interviews above, the researchers analyzed that overall the Camat had done his job well.

This was also explained by the Kerinci Kanan sub-district head about when the village head and village officials had doubts in carrying out their duties whether to hold discussions. Following are the results of the interview:

Yes, that's for sure, if the village head or village officials experience problems and doubts in carrying out their duties, we will have a discussion, but due to the lack of human resources, the development of administrative science for village officials and inadequate equipment support, this makes it a bit difficult for village administration data equipment.

The same thing was also explained by the Head of Kerinci Kanan Village, Mr. Yusrihanis at the Kerinci Kanan Village Office, he said:

The Camat has provided guidance in the village through the head of the sub-district government section regarding technical operational administrative instructions, and if we encounter problems the sub-district will invite us to have a discussion, but the low level of human 
resources and the level of knowledge and inadequate facilities are inhibiting factors for us in carrying out this activity. Duty.

The same thing was also explained by the Head of Kerinci Kiri Village, Mr. Rusli. At the Kerinci Kiri Village Office, he said:

Actually, the sub-district head has done his job well, such as the coaching that has been carried out in the village, but we are aware of the lack of understanding of the work that has been given so that there are doubts and obstacles in carrying out the task. he said:

Followed by an interview with the Head of Bukit Agung Village, Mr. Parlaungan Panjaitan,

As village officials, we only carry out the tasks given to us, but in carrying out our duties we actually still lack facilities so that our level of knowledge is limited to doing work according to existing facilities.

Based on the results of the interview above, the researcher with the Kerinci Kanan Subdistrict and 3 Village Heads, namely the Kerinci Kanan Village Head, Kerinci Kiri Village Head and Bukit Agung Village Head, the researchers analyzed that the obstacles to the village head's work process were inadequate facilities so that there was a lack of understanding of scientific developments. Village administration facilities should be adequate so that there is no doubt in carrying out their duties.

Followed by an interview with one of the people in Kerinci Kanan Village, Mr. Agus as a resident of Kerinci Kanan Village, he said about the facilities at the Kerinci Kanan Village Office. The following are the results of the interview:

The facilities in Kerinci Kanan Village are indeed less like chairs, I as a resident feel uncomfortable when taking care of the required letters and have to wait a long time while standing. Followed by an interview with one of the people in Kerinci Kiri Village, Mr. Sutar as a resident of Kerinci Kiri Village he said about the facilities at the Kerinci Kiri Village Office.

Following are the results of the interview:

As for the facilities, thank God, it's pretty good now, in Kerinci Kiri Village, construction is also underway for a motorbike parking lot and yesterday I also saw that there were additional seats at the Village Office. (On Tuesday, July 2020)

Followed by an interview with one of the people in Bukit Agung Village, Mr. Rahmad as a resident of Bukit Agung Village, he said that there were facilities at the Bukit Agung Village Office. Following are the results of the interview:

Overall, for the facilities that I saw, there were usually seats for residents who were taking care of their interests there, but if there were many who took care of them, they had to queue and some did not get a seat. (On Tuesday, 21 July 2020).

Based on the results of the researcher's interview with one of the people from each village, namely Mr. Agus from Kerinci Kanan Village, Mr. Sutar from Kerinci Kiri Village and Mr. Rahmad from Bukit Agung Village, the researcher analyzed that the Sub-district must conduct a survey and see as a whole about the existing facilities in the village. the village so that in carrying out community services they can feel comfortable and village officials are also not pressured on the grounds of inadequate facilities.

\section{Organization}

Organization is a group of people in a container to cooperate rationally and systematically that is guided or controlled to achieve certain goals, utilizing the resources in it. 
This organizational indicator will explain the responses of informants regarding the Capacity Building of the Camat in Conducting Village Head Coaching in Kerinci Kanan District, Siak Regency. To see the results of the informants' answers to the organizational indicators as follows.

Based on the researcher's interview with the Kerinci Kanan Sub-district Head, Siak Regency, Mr. M. Hassanal Lutfi, S. STP when interviewed at the Kerinci Kanan Camat Office he said about how to carry out oral, written and practical instructions to the village head which was easier to understand. Following are the results of the interview:

In my opinion, as the Camat, I must first understand what they need and what they don't need, if in the delivery of tasks, the village head understands more by direct practice, I will do it in a practical way. But so far, I have done all three, first I gave verbal instructions, after that I gave written notes to make it easier to understand then we did direct practice in the field.

Based on the results of the researcher's interview with the Kerinci Kanan sub-district, the researcher can analyze that to understand the work of the sub-district apparatus, they must also prepare the preparation procedures and stages in carrying out the task, then give verbal and writteninstructions as well as direct practice to make it easier to understand.

Followed by the interview about giving orders to the village head whether the order was carried out according to plan or not. Following are the results of the interview:

Before giving orders, we provide training on procedures for the preparation of both general administration, finance, population, development and BPD. This training is attended by village officials who are expected to be able to carry out their duties properly which are assigned to them without direct direction from their superiors. All of this we do to improve the ability of village officials to serve the community and be able to carry out the orders we give them well.

Based on the results of the interviews above, researchers can analyze that with the training carried out by sub-district officials, the orders given by superiors can be carried out as desired and in providing services to the community provide improvements so that the people served are satisfied with the services provided by village officials.

Followed by an interview with the Kerinci Kanan Village Head, Mr. Yusrihanis at the Kerinci Kanan Village Office as the Kerinci Kanan Village Head, he said about whether the guidance and training provided by the Camat to the Village Head could help in carrying out their duties. Following are the results of the interview:

Alhamdulillah, it really helped us in carrying out village administration, besides that it also improved our ability to serve the community, so that the people we served were satisfied with the services we provided.

Followed by an interview with the Head of Kerinci Kiri Village, namely Mr. Rusli. At the Kerinci Kiri Village Office as the Head of Kerinci Kiri Village, he said about whether the guidance and training provided by the Camat to the Village Head could help in carrying out their duties. Following are the results of the interview:

Yes, it certainly helps, but due to the lack of knowledge of our human resources, all the training and guidance provided by the sub-district apparatus is not carried out thoroughly.

Followed by an interview with the Village Head of Bukit Agung, namely Mr. Parlaungan Panjaitan. At the Village Office of Bukit Agung as the Head of the Village of Bukit Agung, he said about whether the guidance and training provided by the Camat to the Village Head could help in carrying out their duties. Following are the results of the interview:

It really helps us, especially in providing services, now that we can provide better services to the community, we really hope that this guidance and training can be carried out regularly in order to improve our abilities. 
Based on the results of interviews with researchers with the Head of Kerinci Kanan Village, Mr. Yusrihanis, the Head of Kerinci Kiri Village, Mr. Rusli, and the Head of Bukit Agung Village, Mr. Parlaungan Panjaitan, researchers, it can be analyzed that the guidance and training carried out by the sub-district officials is very helpful but it is a pity if there are still one of the villages that still does not understand the training so that it makes the village administration service system unsatisfactory for the community.

The researcher interviewed with one of the people of Kerinci Kanan Village, namely Mr. Agus, he as a resident of Kerinci Kanan said about how the services carried out by village officials served the people of Kerinci Kanan Village. Following are the results of the interview:

The services provided by the village apparatus are quite good, both in terms of communication, providing direction to people who do not understand the procedure, they provide the best for the community so that the community is comfortable in the service process provided by the village apparatus.

Followed by the researcher's interview with one of the people of Kerinci Kiri Village, Mr. Sutar, he as a resident of Kerinci Kiri said about how the services carried out by village officials in serving the people of Kerinci Kiri Village. Following are the results of the interview:

As for service, I am not satisfied with the service of the Kerinci kiri village apparatus, because they do not explain the procedure for making letters. For example, there are residents who want totake care of a child's birth certificate, here they are only limited to providing a paper containing therequirements without explaining. And the time in serving is always not on time.

The researcher interviewed with one of the Bukit Agung Villages, namely Mr. Rahmad, he as a resident of Bukit Agung Village said about how the services provided by village officials in serving the people of Bukit Agung Village. Following are the results of the interview:

Personally, the services provided by village officials are very helpful, because at the Bukit Agung Village Office the employees who are hired understand the service procedures so they understand what is needed by the community, if we experience problems, they will provide directions in a good and polite way.

Based on the results of the researcher's interview with one of the people from each village, namely Mr. Agus from Kerinci Kanan Village, Mr. Sutar from Kerinci Kiri Village and Mr. Rahmad from Bukit Agung Village, researchers can analyze the steps that need to be taken by all parties both providing services ( village apparatus) or those who receive services (community) should cooperate well with each other, namely for village officials by improving the quality of services both in terms of procedures that need to be simplified, clarity of work units and transparency of service costs, then with regard to service time by completing appropriate services time.

\section{CONCLUSION}

Based on the results of the research, what has been done is that the Camat Capacity Building in Conducting Village Head Coaching in Kerinci Kanan District, Siak Regency. The subdistrict head has carried out coaching with the abilities he has, and it can be concluded as follows: The Camat has provided guidance in the form of providing guidance to village officials. In providing guidance, it shows that the Camat as a district government apparatus has carried out itsduties well, but the inhibiting factor is the low resources of the village apparatus so that it become and obstacle in the process of increasing the capacity building of a sub-district head.

The Camat has provided training to village government officials. In providing the training, the sub-district government has been good in carrying out its duties, but the facilities and infrastructure in the training process are still inadequate so that the training process carried out bythe camat is not optimal. 
As a District Government Apparatus, the Camat has also supervised the village apparatus. Supervision carried out by the camat by going to the field, interacting directly with village officials and the community, this proves that the camat has done its job.

Thus, capacity building is not a process that starts from scratch but starts from building the existing potential and then processed to further improve the quality of self, groups, organizations, and systems in order to survive in the midst of an environment that undergoes continuous changeby utilizing cooperation between the sub-district apparatus and the local government Village apparatus.

\section{REFERENCE}

Anni Milen, 2004. Pegangan Dasar Pengembangan Kapasitas. Yogyakarta: Diterjemahkan SecaraBebas Pondok Pustaka Yogya.

Bungin, Burhan. 2001. Penelitian Kualitatif. Jakarta: Kencana.

Haryanto. 2014. Pengembangan Kapasitas Kelembangaan. AP2I Nasional.

Lexy J. Moleong. (2005). Metode Penelitian Kualitatif. Bandung: Remaja Rosdakarya. Ndraha, Talizuduhu.2011. Kybernology (Ilmu Pemerintahan Baru). Jakarta: Rineka Cipta.

Nurcholis, Hanif. 2005. Teori dan Praktik Pemerintahan dan Otonomi Daerah. Jakarta: Grasindo.Rasyid, Ryaas, 2002. Makna Pemerintahan. Jakarta: Yarsif Watampone.

Riyadi Soeprapto, MS. 2010. The Capacity Building For Local Government Toward Good Governance, Word bank.

Santoso, Pandji. 2005. Administrasi Publik - Teori dan Aplikasi Good Governance. Bandung: Revika Aditama.

Santoso, 2005. Pembinaan Dalam Organisasi. Jakarta: Gramedia.Sugiyono. 2015. Metode penelitian kualitatif. Bandung: Alfabeta.

Syafie, Inu Kencana. 2010. Pengantar Ilmu Pemerintahan. Bandung: PT. Rineka Aditama.Syafie, Inu Kencana. 2009. Pengantar Ilmu Pemerintahan. Bandung: Refika Aditama.

Thoha, Miftah. 2008. Birokrasi Pemerintahan Indonesia di Era Reformasi. Jakarta: Kencana Perdana Media Grup.

Thoha, Miftah. 2010. Pembinaan organisasi, Proses dianosa dan Intervensi, Manajemen kepemimpinan. Yogyakarta: Gava Media.

Usman, Husaini. 2009/ Metododlogi Penelitian Sosial. Jakarta: Bumi Aksara.

Wasistiono, Sadu. 2003. Kapita Selekta Penyelenggaraan Pemerintahan Daerah, Bandung: Fokus Media.

Wijaksono, Kristian Widya. 2006. Administrasi dan Birokrasi Pemerintahan. Yogyakarta: Graha Ilmu. Winkel, 2002. Dampak Pembangunan dan Pendidikan Terhadap Kehidupan Sosial Budaya Masyarakat Daerah, Yogyakarta: Depdikbud.

Zulkifli, ddk.2013. Buku Pedoman Penulisan Usulan Penelitian (UP), Skripsi dan Kertas Kerja. Pekanbaru: Badan Penerbit Fisipol UIR.

Arif Setiadi Capacity Building Pengurus Rehabilitasi Berbasis Masyarakat Dalam Pelayanan Terhadap Penyandang Disabilitas Di Kelurahan Babakan Ciparay Kecamatan Babakan Ciparay Kota Bandung. Jurnal Ilmiah Pekerjaan Sosial, Vol. 18 No. 1, Juni 2019

Delpi Susanti, Yendri Nazir. 2016 Peranan Camat Dalam Membina Badan Permusyawaratan Desa Di Kecamatan Ujung Batu Kabupaten Rokan Hulu. Universitas Islam Riau. Jurnal Kajian Pemerintahan Politik dan Birokrasi, Vol.2, No.2 (2016)

Devit Kurniawan, Jusdin Puluhulawa, Sastro M. Wantu. Capacity Building Dinas Pendidikan Dalam Peningkatan Kinerja Guru (Studi Kasus Guru PPKn SMP Di Kecamatan Wonosari Kabupaten Boalemo). Jurnal Riset dan Pengembangan Ilmu Pengetahuan, Vol.2, No.2, Mei 2017

Gayu Naue, Sarah Sambiran, Frans Singkoh Peran Camat Dalam Membina Penyelenggaraan Kegiatan Pemerintahan Di Kelurahan Tengkulu Kecamatan Wanea Kota Manado. Jurnal 
Jurusan Ilmu Pemerintahan, Vol.1,No.1 Tahun 2018

H. Irwandi, Ratnadewi Kebijakan Pemerintah Kecamatan Dalam Pembinaan Dan Pengawasan Pemerintahan Desa Di Kecamatan Sungai Gelam Kabupaten Muaro Jambi. Jurnal Sains Sosio Humaniora, Vol.2, No.2 Desember 2018

Jeniva Dwi Ratnasari, Mochamad Makmur, Heru Ribawanto. Pengembangan Kapasitas (Capacity Building) Kelembagaan Pada Badan Kepegawaian Daerah Kabupaten Jombang. Jurnal Administrasi Publik (JAP), Vol.1, No.3, h. 103-110

Mirnawati, Capacity Building Organisasi (Studi Pada Kelurahan Imopuro Kecamatan Metro Pusat Kota Metro). Jurnal Teropong Aspirasi Politik Islam 15 (3) (2019) $51-67$

Ridha Rahim Allibani, Pembinaan Pegawai Oleh Camat Sebagai Salah Satu Upaya Dalam Mencapai Efektivitas Kerja Pegawai Di Kecamatan Banjaran Kabupaten Bandung. Jurnal Ilmiah Magister Ilmu Administrasi (JIMIA) No.2 Tahun XI Juni 2017

Refida Ayu Meidini, Capacity Building Organisasi Dalam Pelayanan Publik di Kantor Kecamatan Taman Kabupaten Sidoarjo. Jurnal Kebijakan dan Manajemen Publik 2014

Syafhendry, Delpi Susanti. 2018. Evaluasi Tugas Camat Dalam Membina Penyelenggaraan Pemerintahan Desa Di Kecamatan Rokan Hulu IV Koto Kampar. Program Pasca Sarjana Ilmu Pemerintahan Universitas Islam Riau. Jurnal Kajian Pemerintahan, Vol. 4, No. 1 (2018).

Doni, D., Yogia, M. A., Wedayanti, M. D., \& Purwati, A. A. (202 1, February). The Effect of Leadership and Incentives on Employee Performance of Market Retribution. In 2nd International Conference on Social Sciences Education (ICSSE 2020) (pp. 167-171). Atlantis Press.

Fitriyanti, N., Rahman, K., Prayuda, R., Zainal, Z., \& Rosmayani, R. Implementation of government regulations in the implementation of child protection in Rokan Hilir Regency of Indonesia.

di Keamatan, M. P. N. S., \& Hulu, S. Evaluasi Pelaksanaan Peraturan Pemerintah Nomor 45 Tahun 2007 Tentang Persyaratan dan Tata Cara Pengangkatan Sekretaris Desa.

Nasri, H., Nurman, N., Azwirman, A., Zainal, Z., \& Riauan, I. (2022). Implementation of collaboration planning and budget performance information for special allocation fund in budget planning in the regional development planning agency of Rokan Hilir regency. International Journal of Health Sciences (IJHS) Ecuador, 6(S4), 639-651.

Halim, N. A., Rosidi, I., Haris, A., Yesicha, C., \& Riauan, M. A. I. Media dan Politik.

Riauan, M. A. I. (2016). Figur Politik Calon Walikota Pekanbaru Septina Primawati Rusli dan Erizal Muluk Pada Pemilukada Kota Pekanbaru 2011. Medium, 4(2).

Riauan, M. A. I. (2013). Penggunaan Teknologi Komunikasi dalam Penerapan Good Governance. Jurnal Kajian Pemerintahan, 2(2), 102-107.

Sari, G. G., Wirman, W., \& Riauan, M. A. (2018). Pergeseran Makna Tradisi Bakar Tongkang Bagi Generasi Muda Tionghua di Kabupaten Rokan Hilir Provinsi Riau.

Suwaryo, H. U., \& Redjo, H. S. I. (2018). Transformasi Hubungan Pemerintah Pusat Dan Pemerintah Daerah Dalam Pemberian Izin Hutan Tanaman Industri Bagi Swasta Di Provinsi Riau Tahun 2010-2015.

Riauan, M. A. I., \& Shasrini, T. (2017). Dampak Komunikasi Terapeutik terhadap Citra Pelayanan Kesehatan (Studi Kasus di Rumah Sakit Umum Daerah Arifin Achmad Pekanbaru). Jurnal The Messenger, 9(1), 31-43.

Qurniawati, E. F., \& Riauan, M. A. I. (2015). Analisis Framing Pencitraan Pariwisata Indonesia pada Majalah Penerbangan Linker. Editor, 12, 219. 
Riauan, M. A. I., Sari, G. G., Aziz, A., Prayuda, R., \& Sikumbang, A. T. (2020). Refleksi Anomali Makna Perilaku Merokok di Kalangan Dosen Universitas Islam Riau. Bricolage: Jurnal Magister Ilmu Komunikasi, 6(02), 207-222.

Riauan, M. A. I., \& Aziz, A. (2019). Professional Gamer: The Meaning on 'Point Blank Online'Play. Jurnal The Messenger, 11(1), 18-26.

Riauan, M. A. I. (2012). Studi Komparatif Aktivitas Humas Antara Pemerintah Provinsi Riau dengan PT. Cherron Pacific Iindonesia. Medium, 1(1).

Wicaksono, A. (2022, April). Peatlands Restoration Policies in Indonesia: Success or Failure?. In IOP Conference Series: Earth and Environmental Science (Vol. 995, No. 1, p. 012068). IOP Publishing.

Yogia, A. I. M. A., Wedayanti, Z. M. D., \& Purwati, A. A. (2021). The Role of Organizational Culture on Employee Satisfaction and Performance.

Yuza, A. F. (2014). Policy Dynamics on Subdistricts and Various Post-Reformation Implications.

Rajasa, Y.(202 1). Good Governance In Structure Belantik Raya People's Market In Siak District. Jurnal Kajian Pemerintah: Journal of Government, Social and Politics, 11(2), 1-11.

Yogia, A. S. M. A., Rahman, Z. M. D. W. K., \& Purwati, A. A. (202 1). Leadership of Tourism and Culture Department in Development of Cultural Reserves at District Kuantan Singingi.

Zainal, Z., \& Nurdasanah Putri, F. (2021). Government Management in Village-Owned Enterprises in Increasing Village Original Income In Kampar District. 